\title{
POTENTIALS OF AGRO-TOURISM FOR RURAL DEVELOPMENT IN NIGERIA
}

\author{
F.N. Nnadi and C.D. Akwiwu
}

\begin{abstract}
This paper highlights the potentials of agro-tourism for rural development in Nigeria and made policy recommendations for agro-tourism to flourish. The potentials include the promotion of entrepreneurship and industrialization, economic advancement, education and good health of the citizen. It was recommended that for effective operation of agro-tourism, the national policy on tourism should be reviewed to be trendy with modern tenets. Also, private initiative and involvement in tourism should be encouraged. Nominal compilation of actual and potential agro-tourism sites in the nation should be undertaken in addition to launching extension education campaign on agro-tourism.
\end{abstract}

\section{Key words: Agro tourism, rural development}

\section{INTRODUCTION}

The degradation of the environment, poverty and human misery have been responsible for the challenge, quest and clamour for rural development. Thus, a plethora of academics and policy makers have been enmeshed in the search for measures aimed at a reversal. World Bank (1990) acknowledged that over 80 percent of the over 1.15 billion people living below poverty line (US \$ 350 per annum) in developing countries reside in the rural areas. The condition under which these people live is unimaginable and as a result rural residence is perceived by many as synonymous with deprivation and destitution.

Rural areas are characterized by features such as poverty, low income, poor infrastructure, increasing population, low productivity, low entrepreneurship, homogeneous culture, illiteracy, agricultural economy, traditional practices and poorly utilized natural resources (Ijere, 1992; Chambers, 1983; Peil, 1978). Most of these features have been the bane of rural development. Thus, it could be hypothesized that the more evident the features are in a rural community, the more the level of under-development.

Rural development is the process of rural modernization and the magnetization of the rural society leading to transition from traditional isolation to integration with the national economy (World Bank, 1975). Diejomaoh (1973) conceptualized rural development as the "process of not only increasing the level of per capita income in the rural area but also the standard of living of the rural population". Olayide (1979) defined rural development as the process whereby concerted efforts are made in order to facilitate significant increases in rural resources productivity in rural communities. Rural development entails general improvement in all facets of rural living-resource utilization, productivity, monetization income, food, nutrition, health, education, among others.

In pursuit of these goals, various policies and programmes were designed and tried while some are still in place to emancipate the rural poor from the pangs of backwardness. Rural backwardness is a paradox in Nigeria, especially when the superfluous natural endowments of the country sides are considered. The irony has been a widening gap in possession and access by the majority (the poor) and the few (the privileged).

It is, however, unfortunate that the avalanche of development programmes, approaches and strategies put in place by past and present governments have not made appreciable and resounding impacts on rural conditions and livelihood. The vicious cycle of poverty persists. Some of the programmes included National Accelerated Food Production Programme, 1972; Agricultural Development Project, 1973; Operation Feed the Nation, 1975; Green Revolution, 1980; Peoples, Bank of Nigeria, 1987; National Agricultural Land 
Development Authority, 1991, etc.

The failure of most of the programmes and approaches aimed at rural transformation calls for a re-think. One of the measures necessary to ensure effective and efficient improvement of rural communities is sourcing and exploring alternative forms for profitable utilization of the abundant natural resources. Agro-tourism holds prospects in this regard. Agro-tourism builds on and around the resources of the immediate environment. It exploits and harmonizes for attraction and appreciation by mankind the agricultural resources of the environment.

\section{CONCEPT OF AGRO- TOURISM}

Agro - tourism comprises two concepts, - agriculture and tourism. The Chambers Universal Learners Dictionary (1980) simply defined tourism as the industry dealing with tourists. Tourists were defined as people who travel for pleasure. Okoroafor (1995) remarked that a visitor remains a tourist whether the objective of his mission is to transact business, participate in sports, appreciate the culture of his host destination, visit the people's museum and monuments for his intellectual enrichment, participate in conferences, conduct research, fulfill religious obligations, visit a friend or a relative, observe unique flora and fauna in their natural habitats or simply to have a good time. Agriculture on the other hand is the science or art of cultivating land to raise crops; farming: the production of crops, livestock, fishery or poultry and the diverse processes of finance, research, education, communication, engineering, conservation, processing, storage, distribution and marketing (Onweagba, 2000).

Agricultural exploits and potentials could be show - cased for aesthetic values and attraction. The scenery at markets, horticultural and floricultural gardens could glue the sight of a passerby for hours and entertain him to the extent of forgetting his worries and troubles permanently or temporarily. Agro - tourism by mere logic is the practice of agriculture for tourism. It is the practice of utilizing the art and science of producing crops and animals for aesthetics and pleasure. It is the process of creating imagery and ornamentals from agriculture for the appreciation of mankind. Agro - tourism could take people including farmers to attraction centres like game reserves, dams, festivals / exhibitions, farm sites / structures, among others. Indeed, agro- tourism holds prospects for the economy.

\section{AGRO- TOURISM POTENTIALS FOR RURAL DEVELOPMENT}

Agro - tourism has multifarious contributions to make to rural development. The attendant consequences of under-development inflict untold hardship on the citizenry. To allay their indisposition and monetize the economy at a relatively short period, there is need for diversification of opportunities both for the individuals and government. Agro - tourism is one of such areas that should be explored. The potentials include the following:

- $\quad$ As an Invisible Trade:

Agro - tourism is a good source of foreign exchange. People are attracted nationally and internationally to tourist centres. These visitors pay to have access to the sites. Invisible trade in tourism could be used to balance payment in visible trade in other sectors, thus putting the economy on a stronger footing. Sometimes, tourists could purchase some of the produce or products of the centres. According to Okoroafor (1995), the prospects of tourism for foreign exchange earning places it next to the oil sector. Ovation (2000) remarked that the great foreign exchange potentials of tourism necessitated the establishment of International Tourism Exchange Centre in Berlin, Germany. In Nigeria, between 1986 and 1989 , tourism provided foreign exchange to the tone of $\$ 249$ million to the federal government and $\$ 1187 \mathrm{~m}$ to Africa (Okoroafor, 1995). This implies that with articulate policy planning and management, agro- tourism would contribute more meaningfully to the economy, and thus, help to improve the standard of living of the citizens. 


\section{Rural - Urban Integration:}

Agriculture is mostly practiced in the rural areas. Most agro- tourist centres are located in rural environments. The level of patronage to agro - tourist centres is more by urban dwellers than rural dwellers. This could be attributed to the fact that the rural dwellers have been with these centres all through their lives and that urban dwellers appreciate recreation more than rural dwellers. Agro - tourism brings about rural - urban integration as it gives rise to urban dwellers moving to the rural areas where the centres are located to recreate themselves. This integration fosters unity and promotes mutual understanding as urban dwellers interact with rural people and their environment. Even among rural communities, peaceful coexistence exists by virtue of tourism location. These reduce religious, communal, ethnic and inter - tribal clashes. The resultant peace is indispensable for economic growth and greatness. This would provide an enabling environment for the development of the countryside.

According to Zimolzak and Stansfield (1982), tourism is a major way in which money is circulated from wealthy and developed areas to areas that are undeveloped whether within or outside a country. For example, Okoroafor (1995) reported that there were 19, 490 visitors to Yankari National Park in 1992, out of which 14,512 (74.5\%) were Nigerians and 4, $978(25.5 \%)$ were foreigners. On the strength of the rural - urban linkage, Boutros (1993) emphasized the need to promote domestic tourism. Agro - tourism fosters urban -rural migration against rural-urban migration which has been a bane to Nigerian agricultural development. Considering the pivotal position of agriculture in the economy, any measure that reduces rural - urban drift will help the rural economy to improve.

- Promotion of Entrepreneurship and Industrialization:

The Nigerian economy started experiencing depression in the 1980 s following recession in the oil market (Akwiwu, 2005).

Business activities in a depressed economy suffer terribly following low interest rate. Areas that are less monetized suffer also. The worst affected are business activities with monolithic income sources and ostentatious products. Thus, so many of the entrepreneurs are thrown out of job. Agro - tourism components are many and varied. The income sources are diverse and the products are mostly consumptive. Cai (2003) reported that agro - tourism has become more important than agriculture in terms of employment and income generation in some parks in Beijing. Further, he stated that eight zones or components are available there Precision, agriculture zone, Lamb raising zone, Seed zone, Agricultural products, processing zone and Agro - tourism zone and programme. It should be noted that in each of the components, in addition to the visit for aesthetics, the produce and products of the centers are sold for cash to the visitors. These promote and sustain entrepreneurship. Moreso, some individuals are offered employment and most of the investments do not require extensive capital outlay. This is adequate for rural development.

Entrepreneurship and Industrialization perform vital roles in economic advancement. The entrepreneur identifies investment opportunities (Nzotta and Amaechi, 1999). He understands the needs and wants of potential consumers which are not yet filled and designs ways of taking advantage of the situation (Inegbenebor, 1986). As the entrepreneurs turn out their produce such as seeds, seedlings, breeds of animal, etc., some become raw materials for entrepreneurs in the industrial and manufacturing sector. By this process, more entrepreneurs are attracted to the country for investment. In China, according to Cai (2003), Xiaotangshan park has attracted 51 different enterprises.

- Education:

Agro - tourism brings about increased level of awareness and education through exposure. 
Tourists come face to face with the realities of life. They see, touch, hear and sometimes feel things around and outside their environments. Sometimes they ask questions for more detailed information and clarification. There is free flow of genuine information, which is predicated on increasing knowledge. "Travelling is a part of education" goes a popular saying. In another development, agro - tourism entrepreneurs utilize the most modern innovations and technologies to atune their sites and impress on their guests. Thus, most of the centres serve as demonstration sites to farmers within the vicinity and the tourists who sometimes engage in part time or full time farming. Agricultural technologies transfer system has been ineffective over the years (Asiabaka, 2000). Agro tourism could help to bridge the gap between technological discoveries and their utilization. The farmers see the immediate application of technologies and their prospects. This reduces to the barest minimum conservatism, risk aversion and high levels of scepticism to innovations by farmers in the country - side.

- Good Health:

As earlier indicated, Nigerian economy is depressed. Economic depression is often associated with psychological indisposition; worries, tension, pressure, etc. Psychological indisposition predisposes people to such ailments as stroke; hypertension, heart failure and heart attack. Agro - tourism provides recreation. By merely walking past an agro - tourist centre, fresh and cool air, blossoming and blooming flower and the prevalent micro-climate are serene for good health. By actually visiting such a centre, one gets life in abundance by having full romance with nature. One could jettison one's troubles thereby allaying one's indisposition for a more satisfying life. Keeping alive all one's life is a necessity, for a healthy people is a wealthy people.

- Rectification of the Ozone Layer:

The global warming and the attendant effect on the ozone layer would be counteracted with increased agro - tourism practices. The gaseous exchange in the interaction of flowers, trees, animals etc. and the micro - climate developed are necessary for environmental balance following the reckless discharge of toxic and effluent gases into the air.

\section{CONCLUSION AND RECOMMENDATION}

Numerous agricultural resources abound in Nigeria. Most of these have agro - tourism potentials. These should be utilized to the advantage of the citizenry and indeed the economy. The potentials include rectification of the ozone layer, promotion of good health, entrepreneurship/industrialization, education, rural-urban integration and serve as an in visible trade. These could be improved by putting in place different policy measures.

The National policy on tourism should be reviewed to be trendy with contemporary demands. This will overhaul the system and project the actual and potential benefits of the sub-sector for meaningful contribution to the economy.

Agro - tourism should not be left to the government. Private sector initiative and participation should be encouraged. Encouragement in this context should go beyond mere financing. There should be sound protection of entrepreneurs and their enterprises through laws.

There should be articulate education and extension campaign to sensitize Nigerians on the existing agro -tourism potentials. The benefits should be highlighted and a call for action made - investment. Multi-media should be used.

There should be a nominal compilation and record of the existing agro-tourism sites; both the exploited and unexploited. These will provide the benchmark for referrals and 
policy.

The banking industry should be directed and / or encouraged to give loans to investors in agro-tourism with concessionary conditions. This will not only encourage them but also put the business on sound pedestal for effective operation.

\section{REFERENCES}

Akwiwu, C.D. (2005) "Potentials of Agro-tourism in a Depressed Economy", A Ph.D.Seminar Presented at the Dept. of Agricultural Economics, Extension and Rural Development, Imo State University, Owerri.

Asiabaka, C.C. (2000), “ Strengthening Research-Extension - Farmer Input Linkage System (REFILS) Towards Poverty Alleviation in Nigeria" Keynote Paper Presented at the REFILS, Workshop of South-East Zone, Umudike NRCRI, October, 31

Boutros, B. (1993), In: Okorafor, C.N, (1995), Tourism In Nigeria: Progress, Problems and Prospects, Owerri, African Educational Service Ltd.

Cai, J. (2003), 'Peri-urban Agriculture Development in China, Urban Agriculture Magazine, Number 9, April 2003.

Chambers, R. (1983), Rural Development: Putting the Last First, Britain, Longman Scientific and Technical.

Diejomaoh, V.P. (1973), "Rural Development in Nigeria: The Role of Fiscal Policy" Proceedings of the 1972 Annual Conference of the Nigerian Economic Society.

Ijere, M.O. (1992), Leading Issues in Rural Development, Enugu, ACENA Publishers

Inegbenebor, B.(1986) In: Nwaru, J.C. (2001) "Stimulating Entrepreneurship in Nigerian Farm through Sustainable Agricultural Extension System," Privatization and Commercialization of Agricultural Extension Services Delivered in Nigeria: Prospects and Problem, Proceedings of the Seventh Annual National Conference of the Agricultural Extension Society of Nigeria held in Benin.

Nzotta, M.N. and Amaechi, I.N. (1999), "Entrepreneurship and Economic Development in Nigeria" In: Iheriohanma, E.B.J. (ed), Path to Nigerian Political and Economic Development, Owerri, Last Touch Press.

Okorafor, C.N. (1995), Tourism in Nigeria: Progress, Problems and Prospects, Owerri, African Educational Services Ltd.

Olayide, S.O. (1979), "Rural Development Processes" In: Eweka, J.A, Olayemi, S.O. and Bello-Osagie, V.E. (eds), Village Development: Food Basket, Management Strategy, Ibadan, University of Ibadan, Centre for Agriculture and Rural Development

Onweagba, A.E. (2000), “ General Agriculture An Over View” In: Nnadi,

F.N. and Madubuike, F.N. (2000), Introductory Agriculture for Universities and Colleges, Owerri, Education Books and Investment Ltd. in Association with Egeoba Associates.

Ovation International (2002), Ovation Magazine, Issue 42.

Peil, M. (1978), Consensus and Conflict in African Societies, An Introduction to Sociology, Great Britain, Longman.

World Bank (1975), Rural Development, Sector Policy Paper, Washington, D.C., World Bank

World Bank (1990) "Poverty" World Development Report, Washington, D.C., World Bank.

Zimolzak, C.E and Stransfield, C.A. (1982), The Human Landscape:

Geography and Culture, Columbus, Ohio, Charles E. Merrill Publishing Company. 